\title{
Study of efficacy and adverse effect of fluticasone and formoterol combination in bronchial asthma
}

\author{
Sharad Chaddha ${ }^{1}$, Tajinder Kaur ${ }^{2 *}$
}

\begin{abstract}
${ }^{1}$ Department of Pharmacology, Veer Chandra Singh Garhwali Government Medical Sciences \& Research Institute, Srinagar, Uttarakhand, India

${ }^{2}$ Department of Pharmacology, Pandit Bhagwat Dayal Sharma Post Graduate Institute of Medical Sciences, Rohtak, Haryana, India
\end{abstract}

Received: 18 February 2020

Revised: 15 July 2020

Accepted: 11 September 2020

*Correspondence:

Dr. Tajinder Kaur,

Email: atajjinancy@gmail.com

Copyright: (c) the author(s), publisher and licensee Medip Academy. This is an open-access article distributed under the terms of the Creative Commons Attribution Non-Commercial License, which permits unrestricted non-commercial use, distribution, and reproduction in any medium, provided the original work is properly cited.

\begin{abstract}
Background: Bronchial asthma is a chronic inflammatory disorder of the airways associated with airway hyperresponsiveness that leads to recurrent episodes of wheezing, breathlessness, chest tightness and coughing particularly at night or in the early morning.

Methods: This study has recruited 25 newly (male/female) cases of Bronchial Asthma diagnosed on the basis of spirometry in the Department of Pulmonary Medicine, Era's Lucknow Medical College \& Hospital (ELMC\&H). Patients were received Fluticasone/Formoterol (200/10 $\mu \mathrm{g}$ OD). The drugs were administered through metered-dose inhaler (MDI).

Results: The mean forced expiratory volume recorded before treatment $54.92 \pm 4.47$ in a group who were treated with formoterol/fluticasone combination changed to $75.48 \pm 5.03$ after the treatment. No significant adverse effect of this regimens was observed.

Conclusions: The results of this study revealed this regimen showed a significant improvement in lung functions without any significant adverse event.
\end{abstract}

Keywords: Fluticasone/Formoterol, Forced expiratory volume in the first second, Bronchial asthma

\section{INTRODUCTION}

Asthma is a common and potentially serious condition affecting an estimated 300 million individuals of all ages worldwide, comprising $1-18 \%$ of the population in different countries; highest in economically developed countries but rising over time in low- and middle-income countries. ${ }^{1,2}$ It poses a major burden on patients, their families and communities, and on health economies. ${ }^{3}$

Airway hyper-responsiveness and inflammation are also components of the disease. There has been a noticeable increase in the healthcare burden due to asthma globally.
The prevalence and mortality from asthma have shown an upward trend during an era when quality medications are easily available for asthma. ${ }^{4}$

The prevalence of asthma is reported to range from 1.2 to $6.3 \%$ adults in most countries. ${ }^{5}$ On the other hand, diagnosed asthma (i.e. asthma ever diagnosed by a clinician) in adults is generally reported as 2.7 to $4.0 \%$ in most European countries, $12.0 \%$ in England and $7.1 \%$ in the US. ${ }^{6,7}$

There is very limited data on asthma epidemiology from the developing world, including India. However, India is a vast country with immense geographical, racial 
economical, diversity. There are obvious differences in prevalence of disease and approach to management of health problems. In a recent multicentric study, prevalence of asthma in India has been reported to be $2.05 \% .^{8}$

Inhalers are being used for management of asthma for quite some long since the introduction of first pressurized metered-dose inhaler in 1956.

Formoterol is a long-acting $\beta 2$ agonist which has been used for treatment of asthma in monotherapy for quite long. Fluticasone are synthetic glucocorticoids that have shown efficacy in treatment of asthma either alone or in combination with LABA drugs In present study Formoterol/Fluticasone was used in management of bronchial asthma carried out to evaluate safety and efficacy of inhaled formoterol/fluticasone in patients of bronchial asthma. ${ }^{9}$

Formoterol fumarate is a white to yellowish crystalline powder, which is freely soluble in glacial acetic acid, soluble in methanol, sparingly soluble in ethanol and isopropanol, slightly soluble in water, and practically insoluble in acetone, ethyl acetate, and diethyl ether. It is a long-acting selective $\beta 2$-adrenergic receptor agonist ( $\beta 2$-agonist). Inhaled formoterol fumarate acts locally in the lung as a bronchodilator. The pharmacologic effects of $\beta 2$-adrenoceptor agonist drugs, including formoterol, are at least in part attributable to stimulation of intracellular adenyl cyclase, the enzyme that catalyzes the conversion of adenosine triphosphate (ATP) to cyclic-3', 5'-adenosine monophosphate (cyclic AMP). Increased cyclic AMP levels cause relaxation of bronchial smooth muscle and inhibition of release of mediators of immediate hypersensitivity from cells, especially from mast cells.

Fluticasone propionate is a corticosteroid derived from fluticasone used to treat asthma and allergic rhinitis.

In corticosteroid-dependent patients, fluticasone may permit a substantial reduction in the daily maintenance dosage of the systemic corticosteroid and gradual discontinuance of corticosteroid maintenance dosages.

The present study was carried out to observe the effects of inhaled formoterol/fluticasone in bronchial asthma to see the efficacy of formoterol/fluticasone also to observe the change in pulmonary function test from baseline in view of post bronchodilator forced expiratory volume in the first second $\left(\mathrm{FEV}_{1}\right)$.

\section{METHODS}

The study was conducted in Lucknow, the capital of Uttar Pradesh, the most populous state of India having a population of around 40 lacs, providing a true representation of North Indian population and study centre was Departments of Pharmacology and Pulmonary
Medicine, Era's Lucknow Medical College and Hospital, Lucknow the study was conducted after approval from institutional ethical committee. It is interventional, nonblind study of duration of 1year and 6 months from January 2012 to June 2013. The patients included in study were newly diagnosed patients of Bronchial Asthma.

Either gender aged up to 40 years who have consented for inclusion in study and regular follow up on date also patients must be able to understand and follow study related advice,

Patient were not included in study were not willing to give consent, also having renal, cardiac and liver disease. Patient were assessed for improvement of symptoms, compliance, regularities. Assessment was done. The findings on the basis of mean value confirmed the diagnosis of persistent severe asthma in patients as per the GINA guidelines (2010). ${ }^{10}$

A total of 25 patients were first Patients were given 200/10 $\mu \mathrm{g}$ fluticasone/formoterol (FL/F) administered through metered-dose inhaler (MDI) in patients. Pulmonary functions were recorded at baseline and change in pulmonary functions following intervention was recorded. The data was analyzed using Statistical Package for Social Sciences (SPSS) version 20.0.

\section{RESULTS}

A total of 25 patients of bronchial asthma fulfilling the inclusion criteria and not falling in the domain of exclusion criteria were enrolled in the study in which 17 were males and 8 female patients (Table 1,2,3). Prebronchodilator FEV1 absolute values ranged from 0.57 to 2.89 with a mean value of $1.49 \pm 0.63$ while FEV1 \% values ranged from 21 to 91 with a mean value of $47.56 \pm 14.73 \%$ which changed to range from 0.8 to 3.5 and attain a mean value of $1.89 \pm 0.66$ in absolute terms and from 26 to 102 with a mean value of $63.98 \pm 15.17 \%$ in percentage terms (Table 4 ).

Table 1: Age wise distribution of patients.

\begin{tabular}{|llll|}
\hline S. no. & $\begin{array}{l}\text { Age group } \\
\text { (in years) }\end{array}$ & No. of Patients & Percentage \\
\hline 1. & $\leq 10$ & 1 & 4.0 \\
\hline 2. & $11-20$ & 8 & 32.0 \\
\hline 3. & $21-30$ & 11 & 44.0 \\
\hline 4. & $31-40$ & 5 & 20.0 \\
\hline $\begin{array}{l}\text { Mean age } \\
\text { in years }\end{array}$ & $25.5 \pm 5.6$ & \\
\hline
\end{tabular}

Table 2: Distribution of Patients according to gender.

\begin{tabular}{|llll|}
\hline S. no. & Gender & No. of patients & Percentage \\
\hline 1. & Male & 17 & 68.0 \\
\hline 2. & Female & 8 & 32.0 \\
\hline
\end{tabular}


Table 3: Distribution of patients according to occupation.

\begin{tabular}{|llll|}
\hline S. no. & Occupation & No. of patients & Percentage \\
\hline 1. & Farmer & 5 & 20.0 \\
\hline 2. & Labour & 4 & 16.0 \\
\hline 3. & Service & 4 & 16.0 \\
\hline 4. & Shopkeeper & 1 & 2.0 \\
\hline 5. & Student & 9 & 36.0 \\
\hline 6. & Worker & 2 & 8.0 \\
\hline
\end{tabular}

After intervention, $\mathrm{FEV}_{1}$ (Pre) absolute values in Formoterol/ Fluticasone ranged from 0.45 to 2.56 with a mean value of $1.40 \pm 0.58$ and $\mathrm{FEV}_{1}$ (Pre) \% values ranged from 46 to 65 with a mean value of $54.92 \pm 5.01$ which changed to range from 0.69 to 3 with a mean value of $1.71 \pm 0.57$ for absolute and from 61 to 85 with a mean value of $75.48 \pm 5.03$ for percentage (Table 5). Thus, showing a change ranging from 0.08 to 0.9 with a mean value of $0.34 \pm 0.15$ for absolute and from 15 to 27 with a mean value of $20.90 \pm 2.84$ for percentage (Table 6).
Table 4: Outcome of pulmonary function tests at baseline.

\begin{tabular}{|c|c|c|c|c|c|}
\hline & $\mathbf{N}$ & $\begin{array}{l}\text { Mini } \\
\text { mum }\end{array}$ & $\begin{array}{l}\text { Maxi } \\
\text { mum }\end{array}$ & Mean & SD \\
\hline FEV 1 (Pre) & 25 & 0.57 & 2.89 & 1.49 & 0.63 \\
\hline FEV $_{1}$ (Pre)\% & 25 & 21 & 91 & 47.56 & 14.73 \\
\hline FEV $_{1}$ (Post) & 25 & 0.8 & 3.5 & 1.89 & 0.66 \\
\hline FEV $_{1}$ (Post) \% & 25 & 26 & 102 & 63.98 & 15.17 \\
\hline
\end{tabular}

Table 5: Outcome of pulmonary function tests after intervention in (Formoterol/Fluticasone) Group.

\begin{tabular}{|llllll|} 
& N & $\begin{array}{l}\text { Minim } \\
\text { um }\end{array}$ & $\begin{array}{l}\text { Maxi } \\
\text { mum }\end{array}$ & Mean & SD \\
\hline FEV $_{1}$ (Pre) & 25 & 0.45 & 2.56 & 1.49 & 0.58 \\
\hline FEV 1 (Pre) \% & 25 & 46 & 65 & 54.92 & 4.47 \\
\hline FEV (Post) & 25 & 0.69 & 3 & 1.71 & 0.57 \\
\hline FEV 1 Post) \% & 25 & 61 & 85 & 75.48 & 5.03 \\
\hline
\end{tabular}

Table 6: Caparison of change in pulmonary function test after intervention (formoterol/fluticasone) group.

\begin{tabular}{|c|c|c|c|c|c|c|c|c|}
\hline & \multirow{2}{*}{$\mathbf{N}$} & \multicolumn{2}{|c|}{ Before intervention } & \multicolumn{2}{|c|}{ After intervention } & \multicolumn{2}{|c|}{ Change } & \multirow{2}{*}{$\begin{array}{l}\text { Significance of change } \\
\text { (Paired t test) } \\
\text { P }\end{array}$} \\
\hline & & Mean & SD & Mean & SD & Mean & SD & \\
\hline FEV $_{1}$ (Pre) & 25 & 1.49 & 0.63 & 1.40 & 0.58 & -0.09 & 0.43 & 0.143 \\
\hline FEV1(Pre)\% $_{1}$ & 25 & 47.56 & 14.73 & 54.92 & 4.47 & 7.36 & 14.58 & 0.001 \\
\hline FEV $_{1}$ (Post) & 25 & 1.89 & 0.66 & 1.71 & 0.57 & -0.18 & 0.48 & 0.012 \\
\hline FEV $_{1}($ Post $) \%$ & 25 & 63.98 & 15.17 & 75.48 & 5.03 & 11.50 & 16.22 & 0.001 \\
\hline
\end{tabular}

\section{DISCUSSION}

Long-acting $\beta 2$ agonists in combination with inhaled glucocorticosteroids are the mainstay of severe persistent asthma treatment (Masoli, 2004). ${ }^{3}$ The introduction of long acting $\beta 2$ agonists have brought a new dimension to symptomatic treatment. The long-lasting bronchodilation effect of this new class of medications is especially desirable for children, who have longer night rests and more frequent periods of extensive physical activity than most adults. Another advantage offered by long acting $\beta 2$ agonists is their twice a day application, which results in increased patient compliance. ${ }^{11,12}$ Formoterol is a long and rapid acting, selective $\beta 2$ agonist with a bronchodilator effect lasting 12 hours. $^{13}$ Fluticasone is glucocorticosteroid, use of which has recently been started as an adjunct to long acting beta agonist Formoterol and has also shown good response. ${ }^{10}$

In our study Formoterol/Fluticasone group were taken, In this group, post-intervention forced expiratory volume in $1 \mathrm{sec}$ ranged from 46 to $65 \%$ before the use of bronchodilator which changed to 61 to $85 \%$ after the use of bronchodilator thus showing the mean FEV1 to be
$54.92 \pm 4.47 \%$ before the use of bronchodilator which changed to reach at $75.48 \pm 5.03 \%$ after the use of bronchodilator. Thus, on the basis of mean value again showing the presence of severe persistent asthma as per GINA guidelines (2010). ${ }^{10}$

Although, mean values did not show a categorical shift, however, comparison of mean change during the period showed a significant improvement in both prebronchodilator use FEV1 $(7.36 \pm 14.58 \%)$ as well as postbronchodilator use $(11.50 \pm 16.22 \%)$.

The nature of change observed in present study is similar to that of Pearlman et al. (2013) who investigated the efficacy and tolerability of combination of fluticasone propionate and formoterol fumarate for treatment of bronchial asthma and found it to be both safe and efficacious at a dose schedule used by them $(100 / 10 \mu \mathrm{g}$ BID) or that in present study $(100 / 10 \mu \mathrm{g}$ BID or $200 / 20$ $\mu \mathrm{g}$ OD). ${ }^{14}$

\section{CONCLUSION}

Following intervention, no significant change in FEV1 (Pre) absolute value was observed. However, a significant 
increase in FEV1 (Pre)\% and FEV1 (Post)\% was observed. A significant decrease in FEV1 (Post) Abs. value was observed. On the basis of observations in present study, the fluticasone/formoterol showed a significant change parameter associated with forced expiratory volume in 1 second. This combination is very helpful in bronchial asthma patients.

Funding: No funding sources

Conflict of interest: None declared

Ethical approval: The study was approved by the Institutional Ethics Committee

\section{REFERENCES}

1. The International Study of Asthma and Allergies in Childhood (ISAAC) Steering Committee. Worldwide variation in prevalence of symptoms of asthma, allergic rhinoconjunctivitis, and atopic eczema: ISAAC. Lanc. 1998;351:1225-32.

2. Asher MI, Montefort S, Björkstén B, Lai CK, Strachan DP, Weiland SK, et al. ISAAC Phase Three Study Group. Worldwide time trends in the prevalence of symptoms of asthma, allergic rhinoconjunctivitis, and eczema in childhood: ISAAC Phases One and Three repeat multicountry crosssectional surveys. The Lanc. 2006;368(9537):733-43.

3. Masoli M, Fabian D, Holt S, Beasley R, Global Initiative for Asthma (GINA) Program. The global burden of asthma: executive summary of the GINA Dissemination Committee report. Allerg. 2004;59(5):469-78

4. Alderson M. Trends in morbidity and mortality from asthma. Populat Tren. 1987;49:18-2.

5. Aggarwal AN, Chaudhry K, Chhabra SK, D Souza GA, Gupta D, Jindal SK, et al. Prevalence and risk factors for bronchial asthma in Indian adults: a multicentre study. Ind $\mathrm{J}$ Che Disea Alli Scienc. 2006;48(1):13.

6. European Community Respiratory Health Survey. Variations in the prevalence of respiratory symptoms,selfreported asthma attacks, and use of asthma medication in the European Community Respiratory Health Survey (ECRHS). Eur Respir J. 1996;9:687-95.

7. Burney P, Malmberg E, Chinn S, Jarvis D, Luczynska C, Lal E. The distribution of total and specific serum IgE in the European Community Respiratory Health Survey. J Allergy Clin Immunol. 1997;99:314-22.

8. Jindal SK, Gupta D, Aggarwal AN, Agarwal R; World Health Organization; Government of India.Guidelines for the management of asthma at the primary and secondary levels of health care in India. Indian J Chest Dis Allied Sci. 2005;47:309-43.

9. Tamm M, Richards DH, Beghé B, Fabbri L. Inhaled corticosteroid and long-acting $\beta 2$-agonist pharmacological profiles: effective asthma therapy in practice. Respirat Medici. 2012;106:S9-19.

10. GINA (Global Initiative for Asthma). GINA report: Global Strategy for Asthma Management and Prevention, 2007.

11. Harold SN. â-Adrenergic bronchodilators. N Engl J Med. 1995;33:499-505.

12. Barnes PJ. New drugs for asthma. Clin Exp Aller. 1996;26:735-45.

13. Anderson GP. Formoterol: pharmacology, molecular basis of agonism, and mechanism of long duration of a highly potent and selective $\beta 2$-adrenoceptor agonist bronchodilator. Life Sci. 1993;52:2145-60.

14. Pearlman DS, LaForce CF, Kaiser K. Fluticasone/Formoterol combination therapy compared with monotherapy in adolescent and adult patients with mild to moderate asthma. Clin Ther. 2013;35(7):950-66.

Cite this article as: Chaddha S, Kaur T. Study of efficacy and adverse effect of fluticasone and formoterol combination in bronchial asthma. Int $\mathbf{J}$ Basic Clin Pharmacol 2020;9:1509-12. 